\title{
Analisis Tingkat Kesehatan LPD Metode Capital, Assets, Management, Earning dan Liquidity LPD Desa Baluk Negara Periode 2016-2018
}

\author{
Ni Komang Indah Permatasari ${ }^{1}$ \\ Made Dian Putri Agustina ${ }^{2}$ \\ ${ }^{1,2}$ Fakultas Ekonomi, Bisnis, dan Pariwisata Universitas Hindu Indonesia \\ E-mail : komangindah1501@gmail.com
}

Disetujui: 22 Desember 2020

\begin{abstract}
The Village Credit Institution (LPD) is a financial institution belonging to the Pakraman village that has developed, providing social, economic and cultural benefits to its citizens, so it needs to be fostered, improved performance and preserved. The purpose of this study was to determine the level of LPD health using the method of capital, assets, management, earning and liquidity in the LPD at Baluk Village, Negara District for the period 2016-2018. The object of research is the LPD financial statements, especially the balance sheet and income statement at the Pakraman Baluk Village LPD. The population in this study is the financial statements of the LPD Desa Baluk from 2016 to 2018. The sample used in this study is the financial statements which include balance sheets and income statements for the last 3 years, namely 2016, 2017, and 2018. The results of this study indicate that the CAMEL value of the Pakraman Baluk Village LPD in 2016, 2017 and 2018 the health level of the Pakraman Baluk Village LPD is in good health. The suggestion in this research is to create new innovations, for example by making a lucky draw for customers.
\end{abstract}

Keywords : Capital, Assets, Management, Earning, Liquidity

\begin{abstract}
ABSTRAK
Lembaga Perkreditan Desa (LPD) merupakan lembaga keuangan milik desa pakraman yang telah berkembang, memberikan manfaat sosial, ekonomi dan budaya kepada warganya, sehingga perlu dibina, ditingkatkan kinerjanya dan dilestarikan keberadaannya. Tujuan penelitian ini adalah untuk mengetahui tingkat Kesehatan LPD dengan metode capital, assets, management, earning dan liquidity pada LPD Desa Baluk Negara periode 2016-2018. Objek penelitian adalah laporan keuangan LPD khususnya neraca dan laporan rugi laba pada LPD Desa Pakraman Baluk. Populasi dalam penelitian ini adalah Laporan keuangan LPD Desa Baluk dari Tahun 2016 sampai dengan Tahun 2018. Sampel yang digunakan dalam penelitian ini adalah laporan keuangan yang meliputi neraca dan laporan laba-rugi selama 3 tahun terakhir yaitu tahun 2016, 2017, dan 2018. Dari hasil penelitian ini menunjukkan bahwa nilai CAMEL LPD Desa Pakraman Baluk pada tahun 2016, 2017 dan 2018 tingkat kesehatan LPD Desa Pakraman Baluk berada dalam kondisi sehat. Saran dalam penelitian ini adalah menciptakan inovasi-inovasi baru misalnya dengan membuat undian berhadiah untuk nasabah.
\end{abstract}

Kata kunci : Capital, Assets, Management, Earning, Liquidity 


\section{PENDAHULUAN}

Lembaga Perkreditan Desa (LPD) merupakan lembaga keuangan milik desa pakraman yang telah berkembang dan memberikan manfaat sosial, ekonomi dan budaya kepada warganya, sehingga perlu adanya peningkatan kinerja dan pelestarian keberadaannya. Sebagai bagian dari unit desa adat di Bali, LPD berfungsi untuk menyimpan dana dan menyalurkan kredit maupun pinjaman kepada masyarakat yang disesuaikan dengan ketentuan dan Peraturan Daerah Tingkat I Bali, yang mana tujuan dari seluruh sisa hasil usaha yang didapat akan dikembalikan lagi ke pendapatan desa untuk dapat digunakan oleh desa adat setempat dalam rangka membantu perbaikan-perbaikan fasilitas umum yang dimilki (Sanjaya dan Dana, 2018).

LPD sebagai lembaga keuangan milik desa adat, dalam operasionalnya perlu dilakukan pembinaan dan pengawasan. Pengawasan dan pembinaan terhadap Lembaga Perkreditan Desa (LPD) dilakukan oleh BPD. Berdasarkan Peraturan Gubemur Bali Tanggal 7 Maret 2013 No. 11 Tahun 2013 Tentang Petunjuk Pelaksanaan Peraturan Daerah Provinsi Bali No.8 Tahun 2002 Tentang Lembaga Perkreditan Desa Sebagaimana Telah Diubah Beberapa Kali Terakhir Dengan Peraturan Daerah Provinsi Bali No.4 Tahun 2012 Tentang Perubahan Kedua Atas Peraturan Daerah Provinsi Bali Nomor 8 Tahun 2002 Tentang Lembaga Perkreditan Desa Tentang Tata Cara Penilaian Kesehatan LPD dengan metode yang digunakan adalah CAMEL (Capital, Asset, Earning, Management, Liquidity) (Sanjaya dan Dana, 2018).

LPD Desa Pakraman Baluk merupakan salah satu LPD yang masih aktif dalam menjalankan kegiatannya. Sebagai pusat pelayanan dan swadaya pada perekonomian desa, diharapkan agar LPD Desa Pakraman Baluk dpat mendorong pembangunan masyarakat desa melalui tabungan yang terarah serta perjalanan modal yang efektif, memberantas gadai gelap, meningkatkan daya beli masyarakat, melancarkan lalu lintas pembayaran dan pertukaran/peredaran uang di Desa, serta pedekatan pelayanan dalam bidang keuangan di Desa Pakraman. Adapun usaha-usaha yang dilakukan LPD Desa Pakraman Baluk yaitu di bidang perkreditan, bidang simpanan antara lain dalam bentuk tabungan, deposito, dan pinjaman, serta dalam bidang jasa yaitu melayani penerimaan pembayaran listrik dan PDAM.

Data menunjukan bahwa perkembangan total tabungan dari tahun 2016-2017 mengalami penurunan sekitar 15\% yaitu dari Rp 8.903.376.012 menjadi Rp 7.566.218.107 
sedangkan di tahun 2017-2018 mengalami kenaikan sekitar 3\% yaitu dari Rp 7.566.218.107 menjadi Rp 7.808.367.238. Untuk perkembangan total deposito dari tahun 2016-2018 mengalami kenaikan yang cukup signifikan sekitar 95\% yaitu dari Rp 3.716.000.000 menjadi Rp 8.674.000.000. Dan total pinjaman dari tahun 2016-2017 mengalami kenaikan sekitar 8\% yaitu dari Rp 11.254.709.432 menjadi Rp 12.192.631.165 sedangkan tahun 20172018 juga mengalami kenaikan sekitar 13 \% yaitu dari Rp 12.192.631.165 menjadi Rp 13.857.795.245. Total modal juga mengalami kenaikan pada tahun 2016-2018 sekitar 43\% tiap tahunnya. Untuk laba/rugi dari tahun 2016-2018 mengalami penurunan sekitar 7\% sedangkan untuk total asset dari tahun 2016-2018 mengalami kenaikan sekitar 31\% yaitu sekitar Rp 4.973.678.674.

Perubahan kepemimpinan yang terjadi tiga tahun terakhir menimbulkan perubahan sistem transaksi yang sekarang sudah terkomputerisasi, serta dalam penyajian data dalam bentuk laporan keuangan yang semakin baik. Perubahan yang terjadi di dalam system baru LPD membuat pengelolaan data yang lebih cepat dan praktis. Analisis CAMEL khususnya dari segi manajemen yang belum terhitung pada LPD Desa Pakraman Baluk digunakan untuk mengetahui keberhasilan atau perkembangan usaha LPD baik dalam pengelolaan keuangan maupun manajemen usaha.

Mengetahui kondisi kesehatan usaha sangat membantu dalam penentuan kebijakan yang lebih baik kedepannya. Tujuan penelitian ini adalah untuk mengetahui tingkat Kesehatan LPD dengan metode capital, assets, management, earning dan liquidity pada LPD Desa Baluk di Negara periode 2016-2018.

\section{Telaah Literatur Dan Hipotesis}

\section{Permodalan (Capital)}

Menurut Riyanto (2001) modal adalah kolektivitas barang - barang modal yang terdapat dalam neraca sebelah debet, sedangkan yang dimaksud dengan barang - barang modal adalah semua barang - barang yang ada dalam rumah tangga perusahaan dalam fungsi produktifnya untuk membentuk pendapatan. Modal menjadi kebutuhan mendasar bagi perusahaan, bagi Lembaga Perkreditan Desa (LPD), fungsi modal adalah untuk menekan resiko kerugian dan juga penegembangan usaha baik berupa tabungan atau kredit berjangka.

\section{Kualitas Aktiva Produktif (Assets)}

Kasmir (2010:359) menyatakan Aset adalah harta atau kekayaan yang dimiliki oleh perusahaan, baik pada saat tertentu maupun periode tertentu. Asset, adalah harta yang 
dimiliki oleh perusahaan misalnya kas, persediaan, aktiva tetap, aktiva tak berwujud dan lain - lain (Harahap, 2006: 55). Sebagai sumber daya ekonomi yang bernilai serta dapat diukur dengan satuan di dalam suatu perusahaan dengan maksud untuk memperoleh penghasilan sesuai dengan fungsinya.

\section{Manajemen (Management)}

Penilaian manajemen umum difokuskan pada komponen antara lain: (a) strategi/sasaran; (b) struktur organisasi; (c) sistem dan (d) kepemimpinan. Pengisian formulir penilaian manajemen diberikan nilai antara 0/4 dengan kriteria: (0) Tidak sama sekali/ tidak mau dipenuhi, (1) Belum ada tetapi sudah ada rencana untuk memenuhi, (2) Sudah dipenuhi, sebagian besar kurang, (3) Sudah dipenuhi, tetapi beberapa ada yang kurang, dan (4) Sudah dipenuhi, lengkap.

\section{Rentabilitas (Earning)}

Rentabilitas adalah kemampuan perusahaan mendapatkan laba melalui semua kemampuan dan sumber yang ada seperti kegiatan penjualan, kas, modal, jumlah karyawan, jumlah cabang dan sebagainya (Harahap, 2010: 304). Sedangkan meurut Riyanto (2006: 35), Rentabilitas adalah kemampuan suatu perusahaan untuk menghasilkan laba selama periode tertentu. Faktor yang mempengaruhi rentabilitas terdiri dari profit margin yaitu efisiensi perusahaan dengan melihat pada besar kecilnya laba usaha dalam hubungannya dengan sales serta Turnover of operating asset yaitu efisiensi perusahaan dengan melihat kecepatan perputaran operating asset dalam periode tertentu.

\section{Likuiditas (Likuidity)}

Menurut Irham Fahmi (2010:65), Likuiditas adalah kemampuan suatu perusahaan memenuhi kewajiban jangka pendeknya secara tepat waktu. Sedangkan menurut Wiagustini (2010:76), Likuiditas merupakan kemampuan perusahaan untuk memenhi kewajiban finansialnya dalam jangka pendek dengan dana lancar yang tersedia. Likuiditas perusahaan dpat diukur melalui (1) Current ratio kesanggupan perusahaan memenuhi current obligation nya, (2) Quick ratio yaitu perbandingan kas efek, dan (3) Cash ratio untuk mengetahui kemampuan perusahaan membayar hutang yang segera harus dipenuhi dengan aktiva lancar.

\section{Hipotesis}

Tingkat kesehatan LPD Desa Pakraman Baluk ditinjau dari Metode Capital, Assets, Management, Earning, dan Liquidity pada Tahun 2016 sampai 2018 


\section{Metode Penelitian}

\section{Desain Penelitian}

Dalam menganalisis tingkat kesehatan LPD, digunakan analisis rasio yang meliputi Capital, Assets, Management, Earning dan Liquidity atau bisa juga disebut dengan analisis CAMEL. Kerangka berfikir dalam penelitian ini dapat dilihat pada Gambar 1.

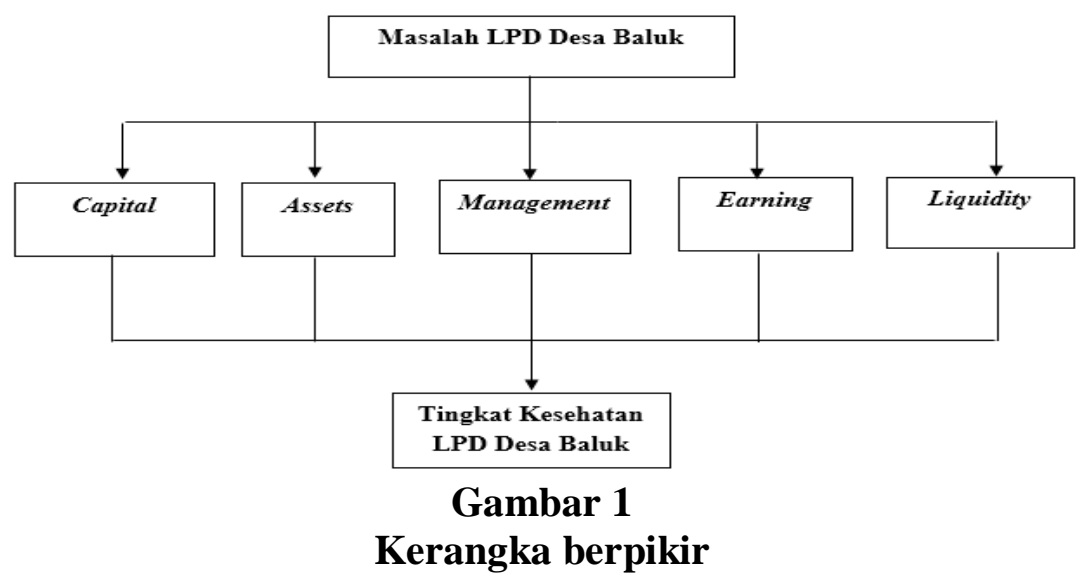

\section{Populasi dan Sampel}

Populasi dalam penelitian ini adalah Laporan keuangan LPD Desa Baluk 2016-2018. Sampel yang digunakan meliputi neraca dan laporan laba-rugi selama 3 tahun terakhir.

\section{Metode Pengumpulan Data}

Pengumpulan data dalam penelitian ini dilakukan dengan cara observasi, wawancara, studi kepustakaan, dokumentasi, dan kuisioner.

\section{Teknik Analisi Data}

1. Analisis kuantitatif adalah analisis dengan menggunakan angka. Analisis ini terdiri dari (a) analisis Permodalan (Capital), (b) Analisis Aset (Assets), (c) Analisis Manajemen (management), (d) Analisi Rentabilitas (earning), dan (e) Analisis Likuiditas (liquidity).

2. Analisis kualitatif digunakan untuk menunjang hasil analisis kuantitatif yang berupa keterangan atau penjelasan tentang hasil dari analisis kuntitatif.

\section{Hasil Dan Pembahasan}

\section{Hasil Analisis}

\section{Analisis Permodalan (Capital)}

Berdasarkan Tabel 1, rasio CAR dan nilai CAR di atas, menunjukkan bahwa dalam Tahun 2016 sampai Tahun 2018 Rasio CAR meningkat sehingga menyebabkan Nilai CAR 
meningkat, dibarengi dengan modal LPD Desa Pakraman Baluk yang meningkat. Berarti Nilai CAR LPD Desa Pakraman Baluk dalam kondisi sehat.

Tabel 1

Kesehatan LPD Berdasarkan Permodalan (Capital)

\begin{tabular}{cccc}
\hline Tahun & Rasio CAR $(\boldsymbol{\%})$ & Nilai CAR & Skor \\
\hline 2016 & 21,80 & 179 & 30 \\
2017 & 23,78 & 198,8 & 30 \\
2018 & 24,98 & 210,8 & 30 \\
\hline
\end{tabular}

Sumber : Data diolah, 2020

\section{Analisis Kualitas Aktiva Produktif (Assets)}

Rasio aktiva produktif yang diklasifikasikan terhadap aktiva produktif dan Rasio cadangan penyisihan penghapusan aktiva produktif yang dibentuk terhadap cadangan penyisihan penghapusan aktiva produktif yang wajib dibentuk.

\section{Tabel 2}

Kesehatan LPD Berdasarkan Kualitas Aktiva Produktif (Asset)

\begin{tabular}{ccc}
\hline \multirow{2}{*}{ Tahun } & \multicolumn{2}{c}{$\begin{array}{c}\text { Aktiva Produktif Yang Diklasifikasikan } \\
\text { Dengan Seluruh Aktiva Produktif } \\
\text { Rasio (\%) }\end{array}$} \\
\hline 2016 & 3.33 & 25 \\
2017 & 5,29 & 25 \\
2018 & 4,64 & 25 \\
\hline
\end{tabular}

Sumber : Data diolah, 2020

\begin{tabular}{|c|c|c|}
\hline \multirow{2}{*}{ Tahun } & \multicolumn{2}{|c|}{ PPAP/CPRR } \\
\hline & Rasio (\%) & Skor \\
\hline 2016 & 100,03 & 10 \\
\hline 2017 & 80,15 & 8,015 \\
\hline 2018 & 81,18 & 8,118 \\
\hline
\end{tabular}

Sumber : Data diolah, 2020

1) Tahun 2016

Rasio aktiva produktif yang diklasifikasikan terhadap aktiva produktif yang dicapai adalah sebesar 3,33\% dengan skor sebesar 25 (maksimum 25), sedangkan rasio cadangan penyisihan penghapusan aktiva produktif yang dibentuk terhadap cadangan penyisihan penghapusan aktiva produktif yang wajib dibentuk yang dicapai adalah sebesar 100,03\% dengan skor 10 (maksimum 10).

2). Tahun 2017

Rasio aktiva produktif yang diklasifikasikan terhadap aktiva produktif yang dicapai adalah sebesar 5,29\% dengan skor sebesar 25 (maksimum 25), sedangkan rasio cadangan penyisihan penghapusan aktiva produktif yang dibentuk terhadap cadangan 
penyisihan penghapusan aktiva produktif yang wajib dibentuk yang dicapai adalah sebesar 80,15\% dengan skor 8,015 (maksimum 10).

3). Tahun 2018

Rasio aktiva produktif yang diklasifikasikan terhadap aktiva produktif yang dicapai adalah sebesar 4,64\% dengan skor sebesar 25 (maksimum 25), sedangkan rasio cadangan penyisihan penghapusan aktiva produktif yang dibentuk terhadap cadangan penyisihan penghapusan aktiva produktif yang wajib dibentuk yang dicapai adalah sebesar 81,18\% dengan skor 8,118 (maksimum 10).

\section{Analisis Manajemen (Management)}

Berdasarkan Tabel 4, penilaian aspek manajemen umum dan manajemen risiko mendapat total nilai 95, setelah jumlah nilai 95 x 10\% diperoleh 9,5 untuk tahun 2018.

\section{Tabel 3}

\section{Hasil Penilaian Manajemen (Management)}

\begin{tabular}{clc}
\hline \multicolumn{1}{c}{ No. } & \multicolumn{1}{c}{ Aspek Manajemen } & Nilai \\
A. & Manajemen Umum & \\
\hline 1 & Strategi & 4 \\
2 & Struktur & 8 \\
3 & Sistem & 16 \\
4 & Kepemimpinan & 12 \\
B. & Manajemen Risiko & 7 \\
\hline 1 & Likuiditas & 11 \\
2 & Pinjaman yang diberikan & 12 \\
3 & Operasional & 12 \\
4 & Hukum & 13 \\
5 & Pemilik dan Pengurus & $\mathbf{9 5}$ \\
\hline
\end{tabular}

Sumber : Data diolah, 2020

\section{Analisis Rentabilitas (Earning)}

Tabel 4

Kesehatan LPD Berdasarkan Rentabilitas (Earnig)

\begin{tabular}{cccc}
\hline \multirow{2}{*}{ Tahun } & \multicolumn{3}{c}{ Laba Sebelum Pajak dan Rata-rata Total Asset } \\
& Rasio $(\boldsymbol{\%})$ & Nilai & Skor \\
\hline 2016 & 6,29 & 419,33 & 10 \\
2017 & 3,57 & 238 & 10 \\
2018 & 4,41 & 294 & 10 \\
\hline
\end{tabular}

Sumber : Data diolah, 2020

\begin{tabular}{cccc}
\hline Tahun & \multicolumn{3}{c}{ Biaya Operasional Terhadap Pendapatan Operasional } \\
Rasio (\%) & Nilai & Skor \\
\hline 2016 & 65,82 & 427,25 & 10 \\
2017 & 77,91 & 276,12 & 10 \\
2018 & 72,79 & 340,12 & 10 \\
\hline
\end{tabular}

Sumber : Data diolah, 2020 
Berdasarkan Tabel 4, perhitungan rasio rentabilitas tahun 2016-2017 menurun 2,72\%, tahun 2017-2018 naik 0,84\%. Perkembangan biaya operasional terhadap pendapatan operasional tahun 20016-2017 meningkat 12,09\%, tahun 2017-2018 menurun sekitar 5,12\%.

\section{Analisis Likuiditas (Liquidity)}

Perhitungan rasio likuiditas tahun 2016-2017 naik 7,26\% dan tahun 2017-2018 menurun $0,91 \%$ skor masing-masing 5 . Perkembangan pinjaman terhadap dana diterima tahun 2016-2017 menurun 7,82\% dan tahun 2017-2018 naik 2,52\% skor masing-masing 5 .

Tabel 5

Kesehatan LPD Berdasarkan Likuiditas

\begin{tabular}{cccc}
\hline \multirow{2}{*}{ Tahun } & \multicolumn{2}{c}{ Rasio Alat Likuid Terhadap Hutang Lancar } \\
& Rasio $(\%)$ & Nilai & Skor \\
\hline 2016 & 32,11 & 642,2 & 5 \\
2017 & 39,37 & 787,4 & 5 \\
2018 & 38,46 & 769,2 & 5 \\
\hline
\end{tabular}

Sumber : Data diolah, 2020

\begin{tabular}{cccc}
\hline Tahun & $\begin{array}{c}\text { Rasio Pinjaman Yang Diberikan Terhadap Dana Yang Diterima } \\
\text { Rasio (\%) }\end{array}$ & $\begin{array}{c}\text { Nilai } \\
\text { Skor }\end{array}$ \\
\hline 2016 & 73,43 & 166,28 & 5 \\
2017 & 65,61 & 197,56 & 5 \\
2018 & 68,13 & 187,48 & 5 \\
\hline
\end{tabular}

Sumber : Data diolah, 2020

\section{Pembahasan}

Berdasarkan analisis tersebut tingkat kesehatan LPD Desa Pakraman Baluk tahun 2016-2018 adalah LPD yang dikategorikan dengan nilai kredit antara 81\% - 100\%, cukup sehat $66 \%$ - <81\%, kurang sehat $51 \%$ - <66\% dan tidak sehat $0 \%-<51 \%$.

\section{Tahun 2016}

Tabel 6, hasil analisis tahun 2016 dengan jumlah 99,4 dalam kategori sehat.

Tabel 6

Predikat Tingkat Kesehatan LPD Desa Pakraman Baluk Tahun 2016

\begin{tabular}{|c|c|c|c|c|}
\hline No. & Faktor/Komponen CAMEL & Rasio & Bobot & $\begin{array}{c}\text { Nilai } \\
\text { Kesehatan }\end{array}$ \\
\hline 1. & CAR & 179 & $25 \%$ & 25 \\
\hline \multirow{2}{*}{2.} & KAP & 127,8 & $25 \%$ & 25 \\
\hline & CPRR & 100,3 & $10 \%$ & 10 \\
\hline 3. & MANAJEMEN & 94 & $10 \%$ & 9,4 \\
\hline \multirow{2}{*}{4.} & ROA & 419,33 & $10 \%$ & 10 \\
\hline & BOPO & 427,25 & $10 \%$ & 10 \\
\hline \multirow{2}{*}{5.} & ALAT LIKUIDITAS & 769,2 & $5 \%$ & 5 \\
\hline & LDR & 166,28 & $5 \%$ & 5 \\
\hline \multicolumn{4}{|c|}{ JUMLAH } & 99,4 \\
\hline \multicolumn{4}{|c|}{ KRITERIA } & SEHAT \\
\hline
\end{tabular}

Sumber : Data diolah, 2020 


\section{Tahun 2017}

Tabel 7, hasil analisis tahun 2017 yaitu 97,51 dalam kategori sehat.

Tabel 7

Predikat Tingkat Kesehatan LPD Desa Pakraman Baluk Tahun 2017

\begin{tabular}{|c|c|c|c|c|}
\hline No. & $\begin{array}{c}\text { Faktor/Komponen } \\
\text { CAMEL }\end{array}$ & Rasio & Bobot & $\begin{array}{c}\text { Nilai } \\
\text { Kesehatan }\end{array}$ \\
\hline 1. & CAR & 198,8 & $25 \%$ & 25 \\
\hline \multirow{2}{*}{2.} & KAP & 114,7 & $25 \%$ & 25 \\
\hline & CPRR & 80,15 & $10 \%$ & 8.01 \\
\hline 3. & MANAJEMEN & 95 & $10 \%$ & 9,5 \\
\hline \multirow{2}{*}{4.} & ROA & 238 & $10 \%$ & 10 \\
\hline & BOPO & 276,12 & $10 \%$ & 10 \\
\hline \multirow{4}{*}{5.} & ALAT LIKUIDITAS & 787,4 & $5 \%$ & 5 \\
\hline & LDR & 197,56 & $5 \%$ & 5 \\
\hline & JUMLAH & & & 97,51 \\
\hline & KRITERIA & & & SEHAT \\
\hline
\end{tabular}

Sumber : Data diolah, 2020

\section{Tahun 2018}

Berdasarkan Tabel 8, hasil analisis tahun 2018 sebesar 97,61 dalam kategori sehat.

\section{Tabel 8}

Predikat Tingkat Kesehatan LPD Desa Pakraman Baluk Tahun 2018

\begin{tabular}{ccccc}
\hline No. & $\begin{array}{c}\text { Faktor/Komponen } \\
\text { CAMEL }\end{array}$ & Rasio & Bobot & Nilai Kesehatan \\
\hline 1. & CAR & $\mathbf{2 1 0 , 8}$ & $\mathbf{2 5 \%}$ & $\mathbf{2 5}$ \\
2. & KAP & 119,1 & $\mathbf{2 5 \%}$ & $\mathbf{2 5}$ \\
& CPRR & $\mathbf{8 1 , 1 8}$ & $\mathbf{1 0 \%}$ & $\mathbf{8 . 1 1}$ \\
3. & MANAJEMEN & $\mathbf{9 5}$ & $\mathbf{1 0 \%}$ & $\mathbf{9 , 5}$ \\
4. & ROA & 294 & $\mathbf{1 0 \%}$ & $\mathbf{1 0}$ \\
& BOPO & $\mathbf{3 4 0 , 1 2}$ & $\mathbf{1 0 \%}$ & $\mathbf{1 0}$ \\
5. & ALAT LIKUIDITAS & $\mathbf{7 6 9 , 2}$ & $\mathbf{5 \%}$ & $\mathbf{5}$ \\
& LDR & $\mathbf{1 8 7 , 4 8}$ & $\mathbf{5 \%}$ & $\mathbf{5}$ \\
\hline & JUMLAH & & $\mathbf{9 7 , 6 1}$ \\
\hline
\end{tabular}

Sumber : Data diolah, 2020

\section{Simpulan Dan Saran}

\section{Simpulan}

Berdasarkan data yanag diperoleh dari hasil analisis dapat ditarik kesimpulan bahwa pada LPD Desa Pakraman Baluk dengan total nilai masing-masing tahun 2016 sebesar 99,4\%, tahun 2017 sebesar 97,51\%, dan tahun 2018 sebesar 97,61\%. Jadi berdasarkan analisis CAMEL dapat diketahui predikat tingkat kesehatan LPD Desa Pakraman Baluk dari tahun 2016 sampai dengan tahun 2018 adalah dalam kategori sehat. 


\section{Saran}

Berdasarkan pembahasan hasil penelitian, kesimpulan berikut beberapa saran yang dapat diberikan :

1. Hendaknyalah tetap menjaga tingkat kesehatan LPD, sehingga masyarakat tetap memberikan kepercayaannya untuk menyimpan dananya di LPD Desa Pakraman Baluk.

2. Hendaknyalah dengan tingkat persaingan yang semakin besar antar LPD, maka pihak LPD diharapkan dapat menciptakan inovasi-inovasi baru untuk menghimpun atau menyimpan dananya serta memanfaatkan fasilitas kredit yang ditawarkan oleh LPD Desa Pakraman Baluk.

3. Hendaknyalah LPD tetap melakukan pemantauan terhadap penggunaan pinjaman yang diberikan serta kemampuan dan kepatuhan debitur dalam memenuhi kewajibannya agar tidak terjadi kredit bermasalah.

\section{Daftar Pustaka}

Harahap, Sofyan Syafri. 2010. Analisis Kritis Atas Laporan Keuangan. Edisi Pertama. Jakarta : Rajawali.

Irham Fahmi. 2010. Analisis Kinerja Keuangan, Cetakan Kesatu, Penerbit ALFABETA, CV Kasmir. 2010. Analisis Laporan Keuangan. Edisi Pertama. Cetakan Ketiga. Jakarta : Rajawali.

Riyanto. 2001. Dasar-Dasar Pembelanjaan Perusahaan, Edisi Keempat, Cetakan Ketujuh, Yayasan Badan Penerbit Gajah Mada, Yogyakarta.

Sanjaya, I.K.W., dan P.E.D.A. Dana. 2018. Analisis Tingkat Kesehatan Lembaga Perkreditan Desa (LPD) Ditnjau Dengan Metode Capital, Assets, Management, Earning dan Liquidity (Studi Kasus pada LPD di Kecamatan Kuta). Jurnal KHRISNA ; Kumpulan Riset Akuntansi, Vol. 9 No. 2, Hal. 71-76

Wiagustini, Ni Luh Putu. 2010. Dasar - Dasar Manajemen Keuangan. Edisi Pertama. Denpasar : Udayana University.' 